\title{
Zapożyczenia w XVI-wiecznym słownictwie medycznym i ich dzisiejsze losy (na materiale zielnika Stefana Falimirza)
}

Słowa klucze: język polski, historia języka, leksyka XVI wieku, terminologia medyczna

Zapożyczenia (łącznie 873 jednostki znaczeniowe) w leksyce medycznej zielnika Stefana Falimirza $O$ ziołach i mocy ich z 1534 roku to zaledwie 27\% całego zasobu tej terminologii u Falimirza (Jankowiak 2005). Nie stanowi to wyjątku na tle innych grup słownictwa specjalistycznego epoki. W innych terminologiach udział słownictwa obcego w XVI wieku jest również niski. Na przykład udział zapożyczeń w słownictwie morskim sięga zaledwie $18 \%$ (Łuczyński 1986). Nieco wyższy - ok. 30\% - jest np. w terminologii technicznej (Biniewicz 1994, 1997) oraz matematycznej (Biniewicz 1992)1.

Badania nad zapożyczeniami w słownictwie medycznym Falimirza pokazały, że nie zachowują się one jednakowo w XVI wieku. Wyraźnie rozpadają się na dwie grupy: 1) zapożyczenia poświadczone w XVI stuleciu tylko w pracach medycznych ${ }^{2}$ (609), które nazwałam zapożyczeniami terminolo-

${ }^{1}$ W innym opracowaniu - Biniewicz (2002: 23-24) - podaje wyższy (39,6 - 49,3\%) udział zapożyczeń w terminologii matematycznej.

2 Teksty medyczne w SPXVI: A. Glaber, Problemata Aristotelis. Gadki z pisma wielkiego philosopha Aristotela... (1535 r.); Szymon z Łowicza, Enchiridion medicinae 
gicznymi (Jankowiak 2008), ewentualnie także w słownikach $(65)^{3} ; 2$ ) zapożyczenia znane w tym okresie także poza tekstami medycznymi (199), czyli mogące pojawić się w każdym typie tekstów; nazwałam je zapożyczeniami nieterminologicznymi (Jankowiak 2009).

Celem niniejszego artykułu będzie porównanie zachowania się zapożyczeń terminologicznych (609) i nieterminologicznych (199) w XVI stuleciu oraz - dochowanych do dziś zapożyczeń z obu grup - we współczesnej polszczyźnie.

\section{XVI wiek}

Pierwsza i zasadnicza różnica pomiędzy zapożyczeniami terminologicznymi i nieterminologicznymi wynika ze wspomnianego już kryterium wyróżnienia obu grup, a więc miejsca ich występowania. Zapożyczenia terminologiczne (609) wystąpiły jedynie w pracach medycznych tego stulecia i uznać je można za polskie terminy medyczne tego okresu. Natomiast zapożyczenia nieterminologiczne (199) pojawiły się w różnych dziełach XVI wieku: naukowych, artystycznych (prozatorskich, wierszowanych), itp.

Kolejna różnica ma źródło w liczebności obu grup zapożyczeń. Szesnastowieczne terminy medyczne są liczniejsze i stanowią niemal $70 \%$ słownictwa medycznego pochodzenia obcego wyekscerpowanego z herbarza Falimirza, podczas gdy zapożyczenia nieterminologiczne, a więc o większym stopniu rozpowszechnienia, stanowią w tym zielniku jedynie $22,8 \%$.

(1537 r.); H. Spiczyński, O ziolach tutecznych i zamorskich i o mocy ich (1542 r.); M. Siennik, Lekarstwa doświadczone (1564 r.), Herbarz to jest ziol tutecznych, postronnych i zamorskich opisanie (1568 r.); W. Oczko, Cieplice (1578 r.), Przymiot (1581 r.); Marcin z Urzędowa, Herbarz polski (1595 r.).

Wymienione dzieła wyzyskane są w SPXVI w niejednakowym stopniu. W kanonie źródeł podstawowych, a więc objętych statystyką, w $100 \%$ wykorzystane zostały prace: A. Glabera, M. Siennika, Lekarstwa doświadczone, W. Oczki, Cieplice. Pozostałe dzieła: Szymona z Łowicza, H. Spiczyńskiego, M. Siennika Herbarz, W. Oczki Przymiot, Marcina z Urzędowa, są w źródłach dodatkowych, cytowanych w SPXVI tylko sporadycznie.

${ }^{3}$ Grupa ta nie będzie przedmiotem analiz w niniejszym artykule. 
Tabela 1. Geneza zapożyczeń

\begin{tabular}{|c|c|c|}
\hline & $\begin{array}{l}\text { Zapożyczenia } \\
\text { terminologiczne }\end{array}$ & $\begin{array}{c}\text { Zapożyczenia } \\
\text { nieterminologiczne }\end{array}$ \\
\hline Łac. & $\begin{array}{l}548(90,1 \%), \text { np.: aucyja alerandry- } \\
\text { na, enorema, gramen, herba fortys, } \\
\text { kokonidyjon, mirabolani belleryci, } \\
\text { oleum de been, rob de nucybus, sor- } \\
\text { bus, teodorykon }\end{array}$ & $\begin{array}{l}125(\mathbf{6 2 , 8 \% )}, \text { np.: ambra, czarna } \\
\text { kolera, gumi, kontryfat, melis, pleura, } \\
\text { rema, tercyjana, urynat, werbena }\end{array}$ \\
\hline Nm. & $\begin{array}{l}\mathbf{1 1}(\mathbf{1}, \mathbf{8} \%) \text { : cytwar, flejtuch, forta, } \\
\text { galsztyn, gatgan, glasgal, glejt, glit- } \\
\text { wasser, gruca, hak, wajnsztan }\end{array}$ & $\begin{array}{l}38 \text { (19,1\%), np.: fijotek, hatun, } \\
\text { imbier, krokos, tug, matz, nyrka 2*, } \\
\text { oddalać, polej, szlak }\end{array}$ \\
\hline Czes. & $\begin{array}{l}\mathbf{1 5} \mathbf{( 2 , 5 \% ) , ~ n p . : ~ a n i e l s k i ~ t r a n k , ~ g r u s z - ~} \\
\text { czyczka, hajdyński trank, jeleni trunk, } \\
\text { kuklik, miesiaczek, miesięcznik } 2, \\
\text { mirzyk, szwestka }\end{array}$ & $\begin{array}{l}6(3 \%): \text { krzyż, nagła śmierć, piżmo, } \\
\text { rumn, trzemdała, twarz }\end{array}$ \\
\hline W1. & $1(\mathbf{0 , 2} \%)$ : memita & $3(\mathbf{1 , 5} \%)$ : agrest 2, facelet, lawenda \\
\hline Fr. & $1(0,2 \%)$ : realgar & $1(\mathbf{0 , 5 \%})$ : piwonija \\
\hline Nieustal. $^{* *}$ & $\begin{array}{l}\mathbf{3 5} \mathbf{( 5 , 7 \% ) , ~ n p . : ~ b r u s c i ~ s p a r a g , ~ g a l l a s , ~} \\
\text { gloryjert, jelenie języczki, lastrak, } \\
\text { nawodzić, olesznik, sumak, trogija, } \\
\text { wronie oko }\end{array}$ & $\begin{array}{l}25(\mathbf{1 2 , 6 \% )}, \text { np.: barwierz, franca, } \\
\text { granatum, limunija, muszkat, opich, } \\
\text { pasternak, roża, starczek, szarłat }\end{array}$ \\
\hline Tur. & - & $1(\mathbf{0 , 5} \%)$ : subet \\
\hline Liczba & 609 & 199 \\
\hline
\end{tabular}

* Liczba przy nazwie oznacza numer znaczenia.

** Grupa ta gromadzi zapożyczenia o nieustalonej (w literaturze przedmiotu) genezie. Wszystkie te przykłady omówiłam w: Jankowiak 2005.

Źródło: opracowanie własne.

W obu typach mamy do czynienia z pożyczkami z różnych - choć dla obu grup tych samych - języków, co pokazuje tabela 1. Przede wszystkim są to zapożyczenia z łaciny, będącej językiem ówczesnej nauki: od 62,8\% w zapożyczeniach nieterminologicznych do ponad $90 \% \mathrm{w}$ zapożyczeniach terminologicznych. Jak widać, większy wpływ łacina miała na te ostatnie. Z kolei o nieco większym udziale zapożyczeń z innych niż łacina języków można mówić w przypadku zapożyczeń nieterminologicznych.

Zarówno w zapożyczeniach terminologicznych $(35 ; 5,7 \%)$, jak i nieterminologicznych $(25 ; 12,6 \%)$ niemałą grupę stanowią pożyczki o nieustalonej 
do końca w literaturze przedmiotu genezie. Swój udział (ok. 3\%) zaznaczyły w obu typach również bohemizmy. Tylko wyjątkową rolę w polskim słownictwie medycznym tego okresu odegrały pożyczki z włoskiego, francuskiego czy tureckiego.

Tabela 2. Charakterystyka znaczeniowa zapożyczeń

\begin{tabular}{|c|c|c|}
\hline & $\begin{array}{l}\text { Zapożyczenia } \\
\text { terminologiczne }\end{array}$ & $\begin{array}{c}\text { Zapożyczenia } \\
\text { nieterminologiczne }\end{array}$ \\
\hline $\begin{array}{l}\text { Nazwy } \\
\text { anatomiczne }\end{array}$ & $\begin{array}{l}14(\mathbf{2}, 3 \%), \mathrm{np} . \text { balsetes, bazylika, } \\
\text { cefalija, forta, glitwasser, kilis, } \\
\text { puls 2, pulsatylis, wul 1, zafena }\end{array}$ & $\begin{array}{l}7 \mathbf{( 3 , 5 \% ) : ~ k r z y z ̇ , ~ m a t e r y j a , ~ m e d y j a - ~} \\
\text { na, nerw, nyrka 1, nyrka 2, twarz }\end{array}$ \\
\hline $\begin{array}{l}\text { Nazwy } \\
\text { fizjologiczne }\end{array}$ & $\begin{array}{l}\mathbf{6}(\mathbf{1 \%}) \text { : gomorea, inkuba, ko- } \\
\text { lostrom, nawodzić, sekundyna, } \\
\text { sperma }\end{array}$ & 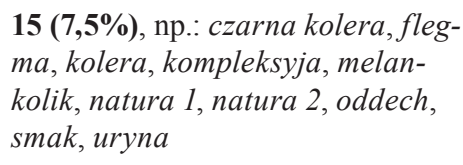 \\
\hline $\begin{array}{l}\text { Nazwy } \\
\text { chorób, } \\
\text { stanów choro- } \\
\text { bowych i ich } \\
\text { objawów }\end{array}$ & $\begin{array}{l}\mathbf{6 8}(\mathbf{1 1}, \mathbf{2} \%), \text { np.: albaras, boleść } \\
\text { połgtowna, brankos, dyjabetes, } \\
\text { enorema, formika, frenezys, mor- } \\
\text { fea, perypleumonija, soda }\end{array}$ & $\begin{array}{l}31(\mathbf{1 5 , 6 \% ) , ~ n p . : ~ a r t e t y k a , ~ f e b r a ~} \\
\text { kwartana, karbunkulus 2, litargija, } \\
\text { miesięcznik 1, nagła śmierć, podo- } \\
\text { gra, purgacyja } 2 \text {, szram, tercyjana }\end{array}$ \\
\hline $\begin{array}{l}\text { Nazwy } \\
\text { związane } \\
\text { z leczeniem }\end{array}$ & $\begin{array}{l}\mathbf{5 2 1}(\mathbf{8 5}, \mathbf{5} \%) \text {, np.: akwa rozata, } \\
\text { flejtuch, katymija argenty, lak wir- } \\
\text { ginis, lumen de koro, massa pitut, } \\
\text { metrydatum, pestylencyjalis, plastr } \\
\text { de gemmis, syropus bizantywus }\end{array}$ & $\begin{array}{l}146 \mathbf{( 7 3 , 4 \% )} \text {, np.: ambra, bezuina, } \\
\text { izop 1, koliryjum, konfekt, kryzo- } \\
\text { litus, massa, merkuryjus, pituła, } \\
\text { trzemdała }\end{array}$ \\
\hline
\end{tabular}

Źródło: opracowanie własne.

Oba typy zapożyczeń nazywają desygnaty z różnych działów ówczesnej medycyny (zob. tabela 2). Przewagę w obu przypadkach mają nazwy związane z leczeniem (73,4\% i 85,5\%). Podobny udział procentowy zapożyczeń terminologicznych i nieterminologicznych dotyczy nazw chorób itd. (11,2\% i 15,6\%). Największe różnice są wśród nazw fizjologicznych, gdzie większy udział (w stosunku do swojego typu) mają zapożyczenia nieterminologiczne.

Pod względem budowy między zapożyczeniami terminologicznymi i nieterminologicznymi zachodzą zarówno podobieństwa, jak i różnice. Do podobieństw zaliczyć należy przewagę nazw jednowyrazowych, chociaż procentowo więcej jest ich w zapożyczeniach nieterminologicznych (96\%). Wśród określeń o takiej budowie jedynie w zapożyczeniach terminologicznych zna- 
lazły się inne niż rzeczowniki części mowy - czasowniki (gargaryzować, nawodzić). Do różnic należy brak - w przypadku zapożyczeń nieterminologicznych - nazw składających się z więcej niż dwóch elementów.

Tabela 3. Budowa zapożyczeń

\begin{tabular}{|c|c|c|}
\hline & $\begin{array}{l}\text { Zapożyczenia } \\
\text { terminologiczne }\end{array}$ & $\begin{array}{c}\text { Zapożyczenia } \\
\text { nieterminologiczne }\end{array}$ \\
\hline $\begin{array}{l}\text { Nazwy } \\
\text { jednowyrazowe }\end{array}$ & $\begin{array}{l}\mathbf{3 8 5}(\mathbf{6 3}, \mathbf{2 \%}) \text {, np:: albijanum, } \\
\text { balsetes, dyjaboraks, gruca } 2, \\
\text { ipokwistydos, lastrak, pamfili, } \\
\text { rafanus, synochus, tyna }\end{array}$ & $\begin{array}{l}191 \mathbf{( 9 6 \% ) , ~ n p . : ~ a g a r y k , ~ c e l i d o n i - ~} \\
\text { ja, gagatek, kamień 3, lektwarz, } \\
\text { majoran, medyjana, pleura, } \\
\text { sandaraka, uryna }\end{array}$ \\
\hline wielowyrazowe & $224(36,8 \%)$ & $8(4 \%)$ \\
\hline dwuwyrazowe & $\begin{array}{l}\text { 199, np.: atomoza rezolucyjo, } \\
\text { emplastrum apostolikum, fluks } \\
\text { emorois, kamień kurowy, massa } \\
\text { piłuł, piłuła aurea, syropus de } \\
\text { endywija, ungentum apostolorum, } \\
\text { winum berberys, ziele paraliżowe }\end{array}$ & $\begin{array}{l}\text { 8: bolum armenum, czarna ko- } \\
\text { lera, febra kwartana, jera pigra, } \\
\text { nagła śmierć, orzech muszkatowy, } \\
\text { piekielny ogień, wapno niega- } \\
\text { szone }\end{array}$ \\
\hline trzywyrazowe & $\begin{array}{l}\text { 23, np.: bol w poł głowy, dyjairys } \\
\text { sekundum Nikolaum, dyjareu- } \\
\text { barbarum frygidum laksatywum, } \\
\text { elektuaryjum de sukko rozarum, } \\
\text { lektwarz wołowego jezyka, massa } \\
\text { piłuł agregatywe, massa piłuł de } \\
\text { agaryko, massa piłuł de lapide } \\
\text { lazuli, poł głowy bolenie, syrup } \\
\text { enule kampane }\end{array}$ & - \\
\hline czterowyrazowe & $\begin{array}{l}\text { 2: muscus dissolutus in aqua rosa- } \\
\text { ta, oksysakra sympleks sekundum } \\
\text { Nikolaum }\end{array}$ & - \\
\hline
\end{tabular}

Źródło: opracowanie własne.

Znaczne różnice pomiędzy zapożyczeniami terminologicznymi i nieterminologicznymi dotyczą czasu ich pojawienia się w polszczyźnie pisanej (zob. tabela 4). Zapożyczenia terminologiczne to niemal w $90 \%$ pożyczki najmłodsze, a więc notowane dopiero w zielniku Falimirza. Tymczasem ponad połowa zapożyczeń nieterminologicznych była znana już w XV wieku, zaś $10 \%$ z nich weszło do polszczyzny pisanej między 1500 a 1534 rokiem. 
Tabela 4. Datacja zapożyczeń

\begin{tabular}{|c|c|c|}
\hline $\begin{array}{l}\text { Przedziały } \\
\text { czasowe }\end{array}$ & $\begin{array}{l}\text { Zapożyczenia } \\
\text { terminologiczne }\end{array}$ & $\begin{array}{c}\text { Zapożyczenia } \\
\text { nieterminologiczne }\end{array}$ \\
\hline I sprzed 1500 & $\begin{array}{l}\mathbf{6 1} \mathbf{( 1 0 \% ) , ~ n p . : ~ a r o m a t y k u m ~ r o - ~} \\
\text { zatum, es ustum, jelenie języczki, } \\
\text { kolostrom, muskus, padajaca } \\
\text { niemoc, saksyfraga, szatsza, turbit, } \\
\text { wronie oko }\end{array}$ & $\begin{array}{l}112 \mathbf{( 5 6 , 3 \% ) , ~ n p . : ~ b a r w i e r z , ~ f a c e l e t , ~} \\
\text { grynszpan, hermodaktyllus, kon- } \\
\text { tryfat, libra, nagła śmierć, rezyna, } \\
\text { topazyjon, wapno niegaszone }\end{array}$ \\
\hline II $1500-1534$ & $1(\mathbf{0 , 2 \% )}$ : lupulus & $\begin{array}{l}20(\mathbf{1 0} \%), \mathrm{np} .: \text { adamas, balsam } 1, \\
\text { fluks, kapar, kassyja, natura } 2, \\
\text { piekielny ogień, powidta, rema, } \\
\text { sałata }\end{array}$ \\
\hline III od 1534 & $\begin{array}{l}\mathbf{5 4 7}(\mathbf{8 9 , 9 \% ) , ~ n p . : ~ a p o s t e m a , ~} \\
\text { dyjaborago, elefancyja, febra kwo- } \\
\text { tydyjana, lapillos, massa pitut de } \\
\text { mesereon, pacena, realgar, syrup } \\
\text { hizopatykus, zafena }\end{array}$ & $\begin{array}{l}\mathbf{6 7}(\mathbf{3 3}, \mathbf{7} \%), \text { np.: aurypigmentum, } \\
\text { bolum armenum, kastoreum, ku- } \\
\text { beba } 2, \text { melankolija } 3, \text { mirabolan, } \\
\text { oddalać, purgacyja 1, sandaraka, } \\
\text { subet }\end{array}$ \\
\hline
\end{tabular}

Źródło: opracowanie własne.

Tabela 5. Podział zapożyczeń na klasy częstości

\begin{tabular}{|c|c|c|}
\hline $\begin{array}{c}\text { Klasy } \\
\text { częstości }\end{array}$ & $\begin{array}{c}\text { Zapożyczenia } \\
\text { terminologiczne }\end{array}$ & $\begin{array}{c}\text { Zapożyczenia } \\
\text { nieterminologiczne }\end{array}$ \\
\hline Klasa częsta $(f \geq 5)$ & $\begin{array}{l}\mathbf{8 4}(\mathbf{1 3 , 8 \% )}, \text { np.: alembik, bal- } \\
\text { neum Maryje, cytwar, epitymum, } \\
\text { gotębia noga, gumi arabikum, } \\
\text { ipostazys, kolokwintyda, psylijum, } \\
\text { sekundyna }\end{array}$ & $\begin{array}{l}\mathbf{1 3 0}(\mathbf{6 5}, \mathbf{3} \%) \text {, np.: bdelijum, dry- } \\
\text { jakiew } 1, \text { galbanum, tot, malon, } \\
\text { mastyka, piżmo, pleura, rema, } \\
\text { rumn }\end{array}$ \\
\hline Klasa rzadka $(\mathrm{f}<5)$ & $\begin{array}{l}\mathbf{5 2 5} \mathbf{( 8 6 , 2 \% )} \text {, np.: balaustyjum, } \\
\text { bazylika, cykatryzans, eruginoza, } \\
\text { felchus, fistyka, matrisilwa, rafa- } \\
\text { nus, ragadyjas, stafisagryja }\end{array}$ & $\begin{array}{l}\mathbf{6 9}(\mathbf{3 4 , 7 \%}), \text { np.: jacynkt, kałkus, } \\
\text { kancer, kassyja, kwarta } 2 \text {, litar- } \\
\text { gija, mirta, plastr, purgować, } \\
\text { storak }\end{array}$ \\
\hline
\end{tabular}

Źródło: opracowanie własne. 
Oba typy omawianych zapożyczeń mają swój wkład zarówno w słownictwo częste, jak i rzadkie. Jednak proporcje w klasach częstości danego typu zapożyczeń są różne, co pokazuje tabela 5. Zapożyczenia terminologiczne zdecydowanie należą do klasy słownictwa rzadkiego (w 86,2\%). Natomiast zapożyczenia nieterminologiczne częściej mają frekwencję powyżej 4 i ponad $60 \%$ z nich należy do leksyki częstej.

Kolejne różnice dotyczą posiadania lub nieposiadania przez omawiane zapożyczenia synonimów (zob. tabela 6). Co prawda w obu typach zapożyczeń są jednostki znaczeniowe, które mają synonimy (od 1 do 55 dla zapożyczeń terminologicznych i do 76 - dla nieterminologicznych), jak i takie, które synonimów nie posiadają. Ponad połowa (57\%) zapożyczeń terminologicznych w XVI wieku nie ma synonimów. I również ponad połowa $(64,3 \%)$ zapożyczeń nieterminologicznych ma synonimy.

Spośród nazw mających synonimy wyróżnić można nazwy posiadające albo wyłącznie synonimy znane z zielnika Falimirza, albo poświadczone tylko spoza niego. W obu typach zapożyczeń najczęściej szeregi synonimiczne składają się z określeń znanych jednocześnie z zielnika Falimirza i innego (dowolnego) tekstu epoki.

Tabela 6. Udział synonimów

\begin{tabular}{|c|c|c|}
\hline Synonimy & $\begin{array}{c}\text { Zapożyczenia } \\
\text { terminologiczne }\end{array}$ & $\begin{array}{c}\text { Zapożyczenia } \\
\text { nieterminologiczne }\end{array}$ \\
\hline $\mathrm{Sa}$ & $\begin{array}{l}262(\mathbf{1}-\mathbf{5 5}) ; \mathbf{4 3} \%, \text { np.: albaras } \\
\text { brankos, elefancyja, febra tercyja- } \\
\text { na, flejtuch, gomorea, herba fortys, } \\
\text { koryza, opilacyja, soda }\end{array}$ & $\begin{array}{l}\mathbf{1 2 8}(\mathbf{1 - 7 6 )} ; \mathbf{6 4 , 3 \%} \text {, np.: hermo- } \\
\text { daktyllus, kancer, kastoreum, } \\
\text { kompleksyja, konfekt, medyjana, } \\
\text { piekielny ogień, rumn, sandaraka, } \\
\text { subet }\end{array}$ \\
\hline Nie ma & $\begin{array}{l}\mathbf{3 4 7} ; \mathbf{5 7 \%} \text {, np.: akkacyja, dyja- } \\
\text { dragantum, elektuaryjum de sukko } \\
\text { rozarum, feces, nefilis, orymez, } \\
\text { panis laktycynijorum, psylonijum } \\
\text { persykum, radyks kani kombusta, } \\
\text { senekrela }\end{array}$ & $\begin{array}{l}\mathbf{7 1} ; \mathbf{3 5 , 7} \% \text {, np.: ametyst, galbanum, } \\
\text { gir, jacynkt, jera pigra, karbunku- } \\
\text { lus } 1, \text { kassyja, koliryjum, kryzolitus, } \\
\text { materyja }\end{array}$ \\
\hline
\end{tabular}

* Synonimy zob. pod odpowiednimi hasłami w: Jankowiak 2006.

Źródło: opracowanie własne. 


\section{XX/XXI wiek}

Prześledzenie losów analizowanych tu dwóch typów XVI-wiecznych zapożyczeń o znaczeniach medycznych we współczesnej polszczyźnie pozwala wskazać na kolejne podobieństwa i różnice między nimi.

Najpierw trzeba zaznaczyć, że przez te kilka stuleci ani przykłady zapożyczeń terminologicznych, ani nieterminologicznych nie zniknęły całkowicie z języka polskiego, co uznać należy za fakt ważny, odzwierciedlający ich trwałość i stabilność. Zwłaszcza że dotyczy to nie tylko faktu przetrwania jednostek znaczeniowych jako takich, ale również znaczeń znanych z XVI wieku.

Tabela 7. Udział liczbowy zapożyczeń dziś

\begin{tabular}{|l|c|c||}
\hline \hline & $\begin{array}{c}\text { Zapożyczenia } \\
\text { terminologiczne }\end{array}$ & $\begin{array}{c}\text { Zapożyczenia } \\
\text { nieterminologiczne }\end{array}$ \\
\hline XVI & 609 & 199 \\
\hline XX/XXI & $\mathbf{4 3 ( 7 , 1 \% )}$ & $\mathbf{1 1 2}(\mathbf{5 6 , 3 \% )}$ \\
\hline
\end{tabular}

Źródło: opracowanie własne.

Pierwsze różnice dotyczą liczby zachowanych dziś nazw. Zdecydowanie bardziej trwałe okazały się zapożyczenia nieterminologiczne, które przetrwały w ponad połowie, gdy tymczasem zapożyczenia terminologiczne nawet nie w $10 \%$ (por. tabela 7). Niewątpliwie wpływ na to miał stopień ich rozpowszechnienia już w tekstach XVI wieku. Występowanie w ówczesnych tekstach nie tylko medycznych, ale i pozamedycznych pomogło w przetrwaniu zapożyczeniom nieterminologicznym.

Z obu typów zapożyczeń zachowały się wyłącznie nazwy jednowyrazowe.

W stosunku do liczby zapożyczeń pochodzących z danego języka zapożyczenia nieterminologiczne przetrwały od ponad 30\% (włoskie) do $100 \%$ (francuskie). Tymczasem zapożyczenia terminologiczne zachowały się najwyżej od ponad 5\% (latynizmy) do 26,7\% (bohemizmy). W obu grupach są języki, z których zapożyczenia nie przetrwały (zob. tabela 8). 
Tabela 8. Geneza XVI-wiecznych zapożyczeń, które zachowały się do dziś

\begin{tabular}{|c|c|c|}
\hline & $\begin{array}{l}\text { Zapożyczenia } \\
\text { terminologiczne }\end{array}$ & $\begin{array}{c}\text { Zapożyczenia } \\
\text { nieterminologiczne }\end{array}$ \\
\hline Łac. & $\begin{array}{l}\mathbf{3 2}(\mathbf{5 , 8 \%}) * \text {, np.: benedykt, flegmon, } \\
\text { gargaryzm, kubeba 1, lepra, mieczyk, } \\
\text { piretrum, puls } 2, \text { pumeks, sperma }\end{array}$ & $\begin{array}{l}\mathbf{6 5}(\mathbf{5 2} \%) \text {, np.: alabaster, apteka, } \\
\text { aptekarz, balsam 1, flegmatyk, migdat, } \\
\text { natura 1, nerw, oddech, paraliz }\end{array}$ \\
\hline $\mathrm{Nm}$. & $2(\mathbf{1 8 , 2 \% )}$ : glejt, hak & $\begin{array}{l}\mathbf{2 5} \mathbf{( 6 5 , 8 \% )} \text {, np.: cebula 1, cukier, figa, } \\
\text { funt, kasztan, krochmal, rzodkiew, } \\
\text { smak, szlak, szpik }\end{array}$ \\
\hline Czes. & $\begin{array}{l}4(26,7 \%): \text { bawetna, gruszczyczka, } \\
\text { kuklik, możdżerz }\end{array}$ & 3 (50\%): krzyż, piżmo, twarz \\
\hline Wł. & nie zachowały się & $1(33,3 \%):$ lawenda \\
\hline Fr. & nie zachowały się & $1(\mathbf{1 0 0 \%})$ : piwonija \\
\hline Nieustal. & $\begin{array}{l}5(\mathbf{1 4 , 3 \% ) : ~ b e z a a r , ~ g a l l a s , ~ l u b s z c z y k , ~} \\
\text { olesznik, sumak }\end{array}$ & $\begin{array}{l}17 \text { (68\%), np.: franca, kapusta } 1 \text {, } \\
\text { kwarta 2, matmazyja, marzana } 1, \\
\text { muszkat, pasternak, roża, ryż, satata }\end{array}$ \\
\hline Tur. & - & nie zachowały się \\
\hline
\end{tabular}

* Procenty odpowiednio w stosunku do XVI-wiecznych latynizmów, germanizmów itd. Źródło: opracowanie własne.

Tabela 9. Chronologia zapożyczeń, które się zachowały

\begin{tabular}{|c|c|c|}
\hline Chronologia & $\begin{array}{l}\text { Zapożyczenia } \\
\text { terminologiczne }\end{array}$ & $\begin{array}{c}\text { Zapożyczenia } \\
\text { nieterminologiczne }\end{array}$ \\
\hline I sprzed 1500 & $\begin{array}{l}\mathbf{8}(\mathbf{1 3}, \mathbf{1 \%} *) \text { : benedykt, berbe- } \\
\text { rys, betonika, kuklik, mieczyk, } \\
\text { możdżerz, pumeks, sumak }\end{array}$ & $\begin{array}{l}\mathbf{7 0}(\mathbf{6 2}, \mathbf{5} \%), \text { np.: barwierz, daktyl, } \\
\text { grynszpan, jarmuz, kamfora } 2, \\
\text { lawenda, marzana 1, migdat, } \\
\text { nyrka 1, oliwa, twarz }\end{array}$ \\
\hline II $1500-1534$ & nie zachowały się & $\begin{array}{l}\mathbf{1 1}(\mathbf{5 5 \%}) \text { : balsam 1, flegma, } \\
\text { kamień 3, kapar, kassyja, kasztan, } \\
\text { kompleksyja, kwarta 2, podogra, } \\
\text { rozmaryn, sałata }\end{array}$ \\
\hline III od 1534 & $\begin{array}{l}35(\mathbf{6}, \mathbf{4} \%), \text { np.: bawetna, bezaar, } \\
\text { cytr } 1, \text { flegmon, glejt, hak, jujube, } \\
\text { lubszczyk, olesznik, puls } 2\end{array}$ & $\begin{array}{l}31(\mathbf{4 6 , 3 \% ) , ~ n p . : ~ a m b r a , ~ a m e t y s t , ~} \\
\text { antraks, arsenik, doktor, febra } 1, \\
\text { flegmatyk, katarakta, krzyż, recepta }\end{array}$ \\
\hline
\end{tabular}

* Procent w stosunku do XVI-wiecznych przedziałów chronologicznych.

Źródło: opracowanie własne. 
Do dziś nie zachowały się zapożyczenia terminologiczne, które weszły do polszczyzny pisanej między 1500 a 1534 rokiem. Zapożyczenia terminologiczne z pozostałych przedziałów czasowych przetrwały (w stosunku do odpowiadających im przedziałów XVI-wiecznych) w zaledwie 6,4\% i 13,1\%. Natomiast największa liczba nazw zachowanych to zapożyczenia znane dopiero od zielnika Falimirza, czyli od roku 1534 (zob. tabela 9). W stosunku do swych przedziałów chronologicznych zapożyczenia nieterminologiczne zachowały się w co najmniej 46\%. Najwięcej przetrwało nazw najstarszych, a więc znanych już w XV wieku.

Tabela 10. Udział synonimów

\begin{tabular}{|c|c|c|}
\hline Synonimy & $\begin{array}{l}\text { Zapożyczenia } \\
\text { terminologiczne }\end{array}$ & $\begin{array}{c}\text { Zapożyczenia } \\
\text { nieterminologiczne }\end{array}$ \\
\hline Są & $\begin{array}{l}\mathbf{3 3}(1-37) ;(\mathbf{1 2}, \mathbf{6} \%), \text { np.: asma, } \\
\text { berberys, betonika, emoroidy } 3, \text { kan- } \\
\text { tarydes, kuklik, lijenteryja, mieczyk, } \\
\text { oftalmija, pistacyja }\end{array}$ & $\begin{array}{l}\mathbf{6 8}(1-55) ;(\mathbf{5 3}, \mathbf{1 \%}), \mathrm{np} .: \\
\text { dryjakiew } 1, \text { granatum, kamień } 3, \\
\text { kardamomum, koleryk, kolika, } \\
\text { krochmal, pasternak, piłuła, syrop }\end{array}$ \\
\hline Nie ma & $\begin{array}{l}\mathbf{1 0}(\mathbf{2}, \mathbf{9} \%) \text { : bawetna, cytr 2, eufor- } \\
\text { bijum, gargaryzm, gruszczyczka, } \\
\text { hak, kolofonija, możdżerz, puls } 2 \text {, } \\
\text { sumak }\end{array}$ & $\begin{array}{l}44 \text { (62\%), np.: cebula 1, cukier, } \\
\text { gagatek, imbier, izop 1, kasztan, } \\
\text { matmazyja, migdat, ryż, szatwija }\end{array}$ \\
\hline
\end{tabular}

Źródło: opracowanie własne.

Z tabeli 10. wynika, że częściej zachowały się zapożyczenia terminologiczne, które miały synonimy, niż te, które ich nie miały. Tymczasem w zapożyczeniach nieterminologicznych proces jest odwrotny: rzadziej dotrwały zapożyczenia posiadające synonimy. Zaznaczyć jednak trzeba, że różnice między zachowanymi zapożyczeniami mającymi synonimy i niemającymi synonimów są nieznacznie mniejsze $\mathrm{w}$ zapożyczeniach nieterminologicznych. Z powyższego wynika też, że w obu typach zapożyczeń na przetrwanie do dziś obcych jednostek znaczeniowych niewielki wpływ miał fakt posiadania lub nieposiadania przez nie wyrazów bliskoznacznych. 
Tabela 11. Status zapożyczeń we współczesnej polszczyźnie

\begin{tabular}{|c|c|}
\hline $\begin{array}{l}\text { Zapożyczenia } \\
\text { terminologiczne }\end{array}$ & $\begin{array}{c}\text { Zapożyczenia } \\
\text { nieterminologiczne }\end{array}$ \\
\hline $\begin{array}{c}43 \\
\text { wszystkie mają status terminów }\end{array}$ & $\begin{array}{l}112 \\
\text { 1) słownictwo podstawowe (10; 8,9\%): apte- } \\
\text { karz, burztyn, gwoździk, lilija, limunija, } \\
\text { małmazyja, natura 1, sałata, smalc; } \\
\text { 2) słownictwo nacechowane } \\
\text { (chronologicznie, potoczne, książkowe) } \\
(\mathbf{1 7 ;} \mathbf{1 5 , 2 \% ) , ~ n p . : ~ b a r w i e r z , ~ d r y j a k i e w ~ 1 , ~} \\
\text { flegmatyk, franca, karbunkulus 1, krzyż, } \\
\text { libra, mirra, szlak, szram; } \\
\text { 3) terminy (85; 75,9\%), np.: antraks, } \\
\text { apopleksyja, arsenik, cynamon, flegma, } \\
\text { kapar, katarakta, koral, mastyka, saletra }\end{array}$ \\
\hline
\end{tabular}

* Procent w stosunku do XVI-wiecznych przedziałów chronologicznych.

Źródło: opracowanie własne

Kolejną różnicą jest status omawianych typów zapożyczeń we współczesnej polszczyźnie (zob. tabela 11). Zasadnicza różnica polega na tym, że zapożyczenia terminologiczne, chociaż zachowało się ich mniej niż zapożyczeń nieterminologicznych, nadal funkcjonują w odmianie języka naukowego. Tymczasem większość zapożyczeń nieterminologicznych wyzbyła się rangi słownictwa ogólnego, możliwego do wystąpienia w każdym typie tekstów. Najistotniejszą zmianą w ich miejscu w języku polskim jest przejście do sfery terminologii.

Kończąc powyższe zestawienie różnic i podobieństw w funkcjonowaniu XVI-wiecznych zapożyczeń terminologicznych i nietereminologicznych, trzeba podkreślić jeszcze raz ich mimo wszystko znaczną trwałość (postaci wyrazowych i znaczeń). Przeprowadzone tu porównanie dotyczyło następujących aspektów: 1) statusu zapożyczeń w XVI i XX/XXI w.; 2) ich liczby, 3) pochodzenia, 4) szczegółowych znaczeń, 5) budowy, 6) chronologii, 7) frekwencji, 8) synonimiki, 9) wpływu tych wszystkich czynników (punkty $1-8)$ na przetrwanie ich do dziś. 
Na podstawie analizy powyższych elementów trzeba stwierdzić, że zarówno w XVI stuleciu, jak i dziś więcej różni niż łączy zapożyczenia terminologiczne i nieterminologiczne. Począwszy od ich liczby w epoce odrodzenia, przez stopień zachowania do XX/XXI w. oraz stopień rozpowszechnienia w polszczyźnie obu okresów. Różnice między zapożyczeniami terminologicznymi i nieterminologicznymi są zarówno mniejsze (procentowy udział języków obcych, udział procentowy w polach tematycznych, budowa), jak i większe (czas wejścia do polszczyzny, procentowy udział w klasach częstości, udział synonimów).

Do podobieństw między zapożyczeniami terminologicznymi i nieterminologicznymi zaliczyć należy przede wszystkim - wspomniany już - sam fakt przetrwania (przynamniej ich części) w polszczyźnie oraz wpływ niemal tych samych języków obcych, a także zdolność do nazywania desygnatów z różnych dziedzin ówczesnej medycyny. Poza tym - przynależność zarówno do leksyki częstej, jak i rzadkiej, pochodzenie z trzech wydzielonych przeze mnie przedziałów czasowych, występowanie zarówno przykładów wchodzących w skład szeregów synonimicznych w XVI stuleciu, jak i jednostek znaczeniowych pozbawionych wyrazów bliskoznacznych.

Jak widać, podobieństwa dotyczą faktu pojawiania się pewnych zjawisk w obrębie omawianych typów zapożyczeń, natomiast zasadnicze różnice wynikają z udziału liczbowego, procentowego tych zapożyczeń.

\section{Bibliografia}

Biniewicz J., 1992, Leksykalne eksponenty stylu naukowego, w: S. Gajda (red.), Systematyzacja pojęć w stylistyce. Materiały z konferencji z 24-26 IX 1991 r., Opole: Wyższa Szkoła Pedagogiczna im. Powstańców Śląskich w Opolu, Instytut Filologii Polskiej, s. 209-214.

Biniewicz J., 1994, Polska terminologia techniczna (O. Strumieński, O sprawie, sypaniu, wymierzaniu i rybieniu stawów, 1573), Zeszyty Naukowe WSP im. Powstańców Ślaskich w Opolu, Językoznawstwo 15, s. 5-10.

Biniewicz J., 1997, Traktat O sprawie, sypaniu, wymierzaniu i rybieniu stawów... Olbrychta Strumieńskiego. Początki polskiego piśmiennictwanaukowego, w: B. Wyderka (red.), Polszczyzna Ślaska. Historia i wspótczesność, Opole: Opolskie Towarzystwo Przyjaciół Nauk, Wydział II Języka i Literatury, s. 19-28.

BinIEwicz J., 2002, Kształtowanie się polskiego języka nauk matematyczno-przyrodniczych, Opole: Wydawnictwo Uniwersytetu Opolskiego. 
Jankowiak L. A., 2005, Stownictwo medyczne Stefana Falimirza, t. 1. Poczatki polskiej renesansowej terminologii medycznej, Warszawa: Slawistyczny Ośrodek Wydawniczy.

JANKowiak L. A., 2006, Stownictwo medyczne Stefana Falimirza, t. 2. Stownik, Warszawa: Slawistyczny Ośrodek Wydawniczy.

JANKowiaK L. A., 2008, Zapożyczenia terminologiczne z zielnika Stefana Falimirza (1534 r.) we współczesnej polszczyźnie, Studia z Filologii Polskiej i Stowiańskiej 43, s. 35-49.

JANKOWIAK L. A., 2009, Szesnastowieczne zapożyczenia nieterminologiczne z zielnika Stefana Falimirza we współczesnej polszczyźnie, [w druku].

ŁucZyŃski E., 1986, Staropolskie stownictwo zwiqzane z żegluga XV i XVI wiek, Gdańsk: Wydawnictwo Morskie.

SPXVI - M. R. Mayenowa, F. Pepłowski (red.), 1966-2004, Stownik polszczyzny XVI wieku, t. 1-22 Wrocław: Zakład Narodowy im. Ossolińskich PAN, t. 23-32 Warszawa: Instytut Badań Literackich.

\section{Borrowings in medical vocabulary in the $16^{\text {th }}$ century and their presence in contemporary Polish (a case study of Stefan Falimirz's herbarium)}

\section{( su m mary)}

The paper presents similarities and differences in the behaviour of the borrowings in the $16^{\text {th }}$ century medical vocabulary, and their presence in contemporary Polish. The comparison concerns the status of the borrowings in the $16^{\text {th }}$ century (division into terminological borrowings and non-terminological ones) and in the $20^{\text {th }}$ and $21^{\text {st }}$ centuries, their numbers, origin, meanings, structure, chronology, frequency, possible synonyms, and the impact of the above mentioned factors on their survival until today. It results from the analysis that non-terminological borrowings survived in a higher number, however, their status in contemporary Polish is different, since most of them have become terms. On the other hand, terminological borrowings, despite the fact that just few of them have survived $(7,1 \%)$, still constitute a part of the specialist vocabulary. 